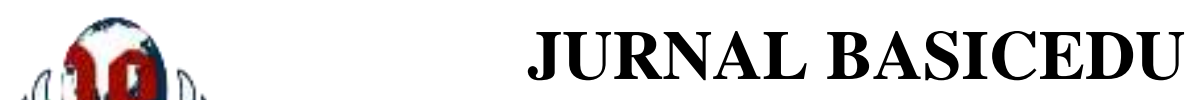

Volume 5 Nomor 6 Tahun 2021 Halaman 5280 - 5287

Research \& Learning in Elementary Education

https://jbasic.org/index.php/basicedu

\title{
Social, Science and Environment Learning Before Covid-19 and the Learning amid Covid-19 in Nursery Students
}

\author{
Bahagia $^{1 凶}$, Rimun Wibowo $^{2}$, Fachruddin Majeri Mangunjaya ${ }^{3}$, Budi Susetyo ${ }^{4}$ \\ Universitas Ibn Khaldun Bogor, Indonesia ${ }^{1,4}$ \\ LPM Equator Bogor, Indonesia ${ }^{2}$ \\ Universitas Nasional Jakarta, Indonesia ${ }^{3}$

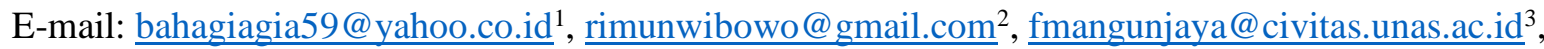 \\ budi.susetyo@uika-bogor.ac.id ${ }^{4}$
}

\begin{abstract}
Abstrak
Penelitian ini bertujuan untuk menemukan pembelajaran sain, sosial dan lingkungan sebelum terjadinya wabah covid. Tujuan lain yaitu untuk menemukan strategi pembejalaran pada masa covid-19 dan prioritas pembelajaran serta tantangan yang dihadapi oleh guru dan orang tua pada masa pembelajaran online. Pendekatan metode penelitian menggunakan pendekatan kualitatif deskriptif. Data dikumpulkan dengan wawancara mendalam guru sekolah pendidikan anak usia dini Dahlia. Sampel dipilih melalui teknik purposive. Hasilnya diteliti dengan cermat melalui teknik triangulasi dan triangulasi sumber. Hasil penelitian menunjukkan bahwa pembelajaran lingkungan dilakukan kepada anak melalui miniatur atau patung hewan dikelas, kemudian membawa anak-anak sekolah ke kebun binatang untuk mengenal hewan-hewan. Ketika sudah berada dikelas guru menanyakan kembali apa yang sudah dilihat dialam. Guru juga membawa anak sekolah ke alam untuk melihat tumbuhan dan hewan yang ada di lingkungan sekitar. Sedangkan untuk mengasah dari sesi sosial, guru membuat berbagai permainan seperti permainan peran menjadi polisi sehingga terdapat kerjasama antar siswa. Kemudian, guru juga menggunakan permainan luar seperti ayunan dimana ada pembelajaran sosial karena harus dikerjakan berdua. Cara lain yaitu memainkan peran sebagai polisi dan sebagian murid lain berperan sebagai penjahat.
\end{abstract}

Kata Kunci: hambatan, sains, alam, lingkungan, Covid-19, sosial

\begin{abstract}
This study aims to find scientific, social, and environmental learning before the covid outbreak. Another goal is to find learning strategies during the Covid-19 period and learning priorities and challenges faced by teachers and parents during online learning. The research method approach uses a descriptive qualitative approach. Data were collected by in-depth interviews with Dahlia's early childhood education school teacher. The sample was selected through a purposive technique. The results were carefully examined through triangulation and source triangulation techniques. The results showed that environmental learning was carried out to children through miniatures or animal sculptures in the classroom, then taking school children to the zoo to get to know the animals. When the teacher was in class, he asked again what he had seen in nature. The teacher also takes school children to nature to see the plants and animals in the surrounding environment. Meanwhile, to hone the social session, the teacher makes various games such as role-playing games to become a police officer so that there is cooperation between students. Then, the teacher also uses outdoor games such as swings where there is social learning because they have to be done together. Another way is to play the role of a policeman and some other students play the role of criminals.
\end{abstract}

Keywords: obstacle, Sains, Nature, Environment, Covid-19, social

Copyright (c) 2021 Bahagia, Rimun Wibowo, Fachruddin Majeri Mangunjaya, Budi Susetyo

Corresponding author :

Email : bahagiagia59@yahoo.co.id

DOI $\quad:$ https://doi.org/10.31004/basicedu.v5i6.1511

ISSN 2580-3735 (Media Cetak)

ISSN 2580-1147 (Media Online)

Jurnal Basicedu Vol 5 No 6 Tahun 2021

p-ISSN 2580-3735 e-ISSN 2580-1147 


\section{INTRODUCTION}

The current Coronavirus (COVID-19) pandemic has impacted and changed lives on a global scale since its emergence and spread from China in late 2019. It has caused millions of infections, and thousands of deaths worldwide (Hager et al., 2020). The coronavirus disease 19 (COVID-19) is a highly transmittable and pathogenic viral infection caused by severe acute respiratory syndrome coronavirus 2 (SARS-CoV-2), which emerged in Wuhan, China, and spread around the world (Shereen et al., 2020). One of the most recent public health emergencies of global concern is the recent COVID-19 pandemic, which started in China and almost infected every country in the whole world. Education is one highly affected by covid-19 (Tria, 2020). The COVID-19 pandemic has become a global health issue and has had a major impact on education. Consequently, halfway through the second semester of the academic year 2019/2020, learning methods were delivered through distance learning (DL) (Amir et al., 2020). Due to the COVID-19 pandemic, the government around the world has closed all the educational institutions to control the spread of disease, which is creating a direct impact on students, educators, and institutions. The sudden shift from the physical classroom to virtual space is creating a disruption among students (Chandra, 2021). As a result, all countries must protect their citizens, one of them children. The government prohibits face-to-face learning activities directly in the classroom. So that learning activities can still take place then use the media on the net (online). As a first measure, the government locked down Wuhan and encouraged people to shut down their businesses and daily activities, staying indoors to contain the spread. Local travels and flights were banned (Sopralda, 2019). When the number of cases started to increase in China, other cities also closed access from other residents entering to keep their citizens safe (Bangura et al., 2020).

To combat the covid-19 catastrophe, many methods can be applied to deal with these issues. Most participants were also taking precautions such as avoiding crowds $(83.4 \%)$ and practicing proper hand hygiene $(87.8 \%)$ in the week before the movement control order started (Azlan et al., 2020). The other way to contain this hurdle is through physical distancing, and quarantine measures were mandated. To meet this mandate while trying to maintain the status quo, various types of human behavior (e.g., shopping, learning, working, meeting, and entertaining) shifted from offline to online, resulting in an accelerated diffusion of emerging digital technologies among ordinary people, while the digital divide further increases between citizens with versus without access to the technologies (Vargo et al., 2021). Education is one sector that receives the detrimental effect of covid-19 catastrophe because schools must be ceased for learning face-to-face in class. For this reason, the transformations that are taking place are affecting the teaching profession itself, while education professionals must adapt to the new situation (Espino-Díaz et al., 2020). The impact of the Coronavirus disease 2019 (Covid-19) pandemic is now beginning to spread to the world of education.

This is done as an effort to prevent the spread of Covid-19 transmission. It is hoped that all educational institutions will not carry out activities as usual; this can diminish the spread of Covid-19. The same thing has been done by various countries that are exposed to this disease, lockdown or quarantine policies carried out to reduce the interaction of many people who can provide access to the spread of the Covid-19 (Abidah, 2020). Lockdown has forced education sectors to implement innovations in teaching, changing the teaching mode, converse all offline courses into online mode both in synchronous and asynchronous learning experiences. The purpose is to enable the students ${ }^{\text {'ee }}$ engagement in the learning process (Puspitasari et al., 2021). The COVID19 pandemic produced widespread disruption to schooling, impacting $90 \%$ of the world's students and moving entire school systems to remote and online learning (Gore et al., 2021). This transformation implies that the expenditure or cost of learning is higher due to the dependence of internet quotas in education, and this is a challenge in itself for weak economic groups, who are already suffering during a pandemic, let alone facing an uncertain educational situation (Abidin \& Tobibatussa'adah, 2021). The COVID-19 pandemic has provided us with an opportunity to pave the way for introducing digital learning (Pokhrel \& Chhetri, 2021). 
The adaptation of the learning system from face-to-face to digitalization results in drawbacks. Students face a burden when they follow online learning. Most websites mentioned students' hardship in learning from home caused by the lack of learning resources such as not having access to the internet and parents' ability to support their children learning (Putra et al., 2020). It is supported that the participants showed a positive perception of the usefulness and ease of online learning systems during pandemic Covid-19. Still, more than half of the teachers didn't agree on its effectiveness. Even though the teachers face many online teaching process problems, they could show the right attitude toward using technology to teach online (Rahayu \& Wirza, 2020). Despite learning based on digital technology leading to numerous issues, it relies on the motivation of students in the joint online class. Intrinsic motivation was indicated to impact more than its counterpart for the students in their online learning participation due to the co-exist case (Gustiani, 2020). Conversely, the student at school can gain benefits from online learning. Children of today have been surrounded by digital technology since their birth; ever since, their everyday life and practices have been entwined with social media, smartphones, tablets, and Internet use. Digital technology has been thoroughly embedded with how they live and learn. They have started interacting with digital technology already as toddlers if not even earlier, and their adult life will for sure be thoroughly embedded and intimately intertwined with digital technology (Iivari, Sharma, \&VentäOlkkonen, 2020). Based on previous research show that online learning at school face to hurdle where the student overdue come to online learning as well as the student have the misery to mix with online class because networking and economic condition. What is more online learning leads students sluggish to get up in the morning time. As a result, the students are short of discipline. In this research, researcher intent to investigate the materials in nursery students where the teachers are impossible to release in the covid era such as learning of sains, social learning through role-play and play a game outside and inside of class. Another goal is to trace the strategy of teachers in learning to contain the covid-19 outbreak for supporting nursery students to gain proper material of teaching. Then, find out about the hurdle that teachers and parents face when the transformation of learning from face to face to online.

\section{METHOD}

The research about Social, Science and Environment Learning before Covid-19 and The Learning amid Covid-19 in Nursery Student was conducted at Dahlia Early Childhood Education School, Bogor. The studies use qualitative research with a descriptive approach. Qualitative research is data collection in a natural setting with the intention of interpreting the phenomena that occur where the researcher is the key instrument, sampling of data sources is carried out purposively, and snowballing, collection techniques are triangulation (combined), inductive/qualitative analysis, and research results. Qualitative research emphasizes meaning rather than generalization (Anggito \& Setiawan, 2018). (Rukajat, 2018) Qualitative research has the following characteristics, namely: In qualitative research, disclosure of meaning (meaning) is essential, natural setting is used as a direct data source where the researcher himself is a key instrument. The objectives of qualitative research are (1) to describe the object of research (Describing Object), (2) to reveal the meaning behind the phenomenon (exploring meaning behind the phenomenon). To determine the sample, the research uses the purposive sampling technique.

Wheres, to select the sample, the researcher used the purposive sampling technique. This way is applied because the researcher gathers a sample which they can reply to the question research conform to the goal of research. The sample is the teacher in Dahlia Bogor Early Childhood Education School namely Sartika. The sample is selected because the teacher was able to answer all the questions which the researcher rose to her. Moreover, she is the best teacher in that school which she has the ability in learning for nursery students. Data are collected including the learning in social, science, and environment (plants and animals) which was performed before the covid-19 outbreak impact school. Furthermore, the question related to applying social aspects through the game and role-play outside of the class will be demanded by a teacher for replying. In 
addition, the researcher asked the question related to the strategy of teachers and the focus of learning amid the covid-19 outbreak. Then, the question about what is the obstacle amid online learning in covid-19. In order to collect the data above, the researcher exerts video calls through whats app several times and records the voice of respondents. There are three times when the researcher called the sample to make sure that teachers have answered all of the questions regarding the purpose.

Once the interview is completed, the researcher tries to analyze the persistence of respondents about the answer. As the result is consistent, no answer is different in the first time interview and the last time, meaning that the result is valid based on social aspects namely student. The data which come from interviews must be combined with numerous collecting data methods to obtain more perfect data from the field. Observation can be mentioned as collecting data from observing directly, such as viewing objects and locations or real. Data will be investigated and analyzed by triangulation data to obtain valid data. Triangulation can be defined as mixing some way to gather valid data. Suciana (2018) said that there is two triangulation including time and technique. Triangulation time is to collect data based on time (morning, daylight, and evening). The data which come from several methods and combine them together can attaint the best data in this research because the sources are based on some sources of the method such as observation, interview, and documentation. It is reliable data from this research.

\section{RESULT AND DISCUSSION}

Teachers face some obstacles like having the misery to make students comprehend the subject that the teacher distributes to their parents. When the covid-19 pandemic, the teacher must render material to parents and teachers ask parents to instruct their children. While parents face hurdles because they must accompany their children. Parents also have a burden to explain the material to teachers. Then, children have lack motivation in participating learning process because their parents can't adjust to their children tampering along at home. Once after this method can't be pursued because it leads to a strong detrimental impact, among the teacher conduct conference through inviting all of the teachers at school. It is similar that teacher requires to alter the method to attain the goal of education. In order to keep education running, educational institutions have had to quickly adapt to the situation (Teräs et al., 2020). The method must be transformed to the other way like video calling in WhatsApp. In this school, This method is better than the previous way because the children can build links to the teachers immediately. There are three teachers, one teacher calls their pupil. Video calls can also connect face to face online. The number of pupils is around 20 people. One teacher must teach 12-15 early students. There is a limited number of pupils who involve in a video call is about 8 students. In this section, students adapt to the covid-19 outbreak by transforming the way of teaching to technology.

In another finding show that teacher use mixing method to teach the children. Teacher problem-solving strategies include implementing blended learning, creating learning groups, regular visits to students, partnering with parents, adapting teaching plans, optimizing electronic media, and utilizing creative media (Munastiwi, 2021). It is exacerbated by the deficiency of online learning through whats app (Magdalena et al., 2021). There are several obstacles, namely signal interference, full cellphone memory, lack of memory Interaction, it is difficult to know the seriousness of students' learning, lack of student learning motivation, online learning support facilities, and difficulty understanding the material provided, as well as in this study describe the solutions carried out to overcome obstacles that occur from using WhatsApp as a learning medium in the network during the Covid-19 pandemic. Nonetheless, these obstacles can be overcome with the help of teachers who should adapt their teaching strategies to the needs of students. In order to do so, experience and knowledge about teaching in the online environment are necessary (Coman et al., 2020). Teachers are stepping up their preparedness in containing the negative effects of this epidemic by bringing in pedagogical strategies at ensuring that students in examination classes are adequately prepared for the examinations In pandemic covid- 
5284 Social, Science and Environment Learning Before Covid-19 and the Learning amid Covid-19 in Nursery Students - Bahagia, Rimun Wibowo, Fachruddin Majeri Mangunjaya, Budi Susetyo

DOI: https://doi.org/10.31004/basicedu.v5i6.1511

19, not all of the subject must be distributed to student because there is priority that teacher must reach amid pandemic such as reading, writing and calculating (Sintema, 2020).

Meanwhile, in the previous time where the pandemic has not combated the human, there are some subjects such as my environment, my vehicle, understanding myself, and my family as well as the universe. Some of these materials must differ when the covid-19 strike human life. We have a plan that we exert zoom meetings as learning media but some parents can't operate this program. Meaning that parents do not have the skill to involve in technology. Even their children are more skilled than their parents in utilizing the technology (Ain et al., 2021). Wheres, parents have a role to take a part in student learning to support the children (Asmawati, 2022). Based on this circumstance, digital literacy in learning is needed for parents. It is similar to the goal of digital literacy is to jump the capacity in critical, creative, and positive mindset in applying digital technology in daily life (Sutrisna, 2020). Teachers must make a prominent for these materials because of student necessities. As they continue to a higher level of education like basic education or elementary school, the school rebuff the student who they are unable to do reading, writing, and calculating. In order to apply the teaching at school, the teacher must approach their parent without intruding. As parent compel their children, the teaching can't be absorbed by the pupils. Meaning that parents should wait for their children until they are keen to participate in learning. Teachers can't complete the pupils to embroider in learning. Method of teaching must rely on student character.

Moreover, teachers gather some material like videos from youtube to be shared with the students for circumventing boredom. Before lockdown, the teachers gather 5 students in one house of the teachers for learning and some teacher at school. In school must be 6 students. The students face stress because the students talk to the teacher that they are boring about online learning. As students don't intend to mix the learning, even one student hates to conduct learning such as teacher ask for write, take a picture and reading but the student hesitates to learn. The teacher can't complete the student. Basically, the student feels cheerful when they meet face to face with their teacher and their classmate when the learning is performed in class rather than online. Meanwhile, the parents face the obstacle of how the parent explains the material to the students. Another defiance of parents is economic where the parents can't pay for tuition fees.

The most essential of material in nursery students before online is to understand about theirself. For example, most students like religion, environment, learning about reading. The teacher looks for what is the most they like. Initially, when they join the class, the teacher recognizes themself and sings a song. The objective is to secure themselves from the news person. In this teacher explain part of their body which the new person may not touch. The goal is to protect themselves from the new person. Before covid-19, children were taught about science like the universe, my vehicle. In the universe lesson, children learn through pictures how the process of rain occurs because there are pictures of the process of rain. Besides that, there are also songs about the universe such as scenery and rainbows. Children are taught drawing because children are very happy with colors and shapes. Even the walls of the school must be colorful and decorated so that the walls of kindergarten school children are colored. They will be interested in participating in school learning if there are many kinds of colors. Children also really like singing. For example, when the children are noisy in class and the atmosphere is chaotic, but if there is singing, the children immediately gather again and the class is neat again. In addition, kindergarten children are very happy with dancing or moving. Young children may be very fond of art. Religious songs are also liked by kindergarten children. To teach the environment, kindergarten children are brought to the field once a month. They exercise first then make a game. At that time, some people will ask about animals, for example, butterflies passing by. In this way, children will know firsthand the animals that exist in the universe. In addition, children are also taught through fruit sculptures, cars, and animals through teaching aids in class.

Miniature plants can be directly seen by them even though they have not seen the original form of what is being demonstrated. In this case, the teacher combines religious tools such as miniature plants with what the students draw. They like both religious songs and singing in general. In addition, teachers regulate children's 
behavior by cleaning. The teacher applies neatness as in the playroom. If you play later, all the toys must be tidied up, if later they are not tidied up, tomorrow they are no longer allowed to play in that room. This learning method proves that there are consequences for what he does. When you don't obey the rules, the child gets the consequences. Another way is to throw trash in its place. Another method is through an example model, for example, there is one child in the class named Meisa. For example, if a friend spills water, he will immediately say that it is dirty. If there is a friend who behaves dirty for example food stuck on the table then he will clean it with a tissue. Another way to grow children's behavior towards the environment is by visiting the zoo and visiting the deer park in the Cifor area, Bogor, West Java. Once the visit is completed, the students ask to repeat what they have observed and what sorts of animals that they have been enticed in the zoo animals. After the visit from the zoo, the teacher will try to ask the children what they have seen at the zoo. Children will be asked to tell stories using miniatures so that they recall memories from the children. There is a repetition of memories to children because what children see at the zoo will look the same as what they see in miniature. This method is very effective for comparing what is observed in the field with what is a statue of each animal and plant that is seen.

The important thing is that the song has a tone. Teachers also have ways to regulate the behavior of kindergarten children. Children who are still at kindergarten level have not behaved regularly. In the beginning, regulating children's behavior is very difficult but it can be successful because among many children there are children who behave well. Teachers will make children behave well. Children who have good behavior will be an example for other children. The other kids will follow. The second way, for example, is that there is a child in the class who doesn't want to wear clothes. When attending class, the child takes off his clothes instead. The child admitted that the atmosphere was very hot and did not like wearing clothes that had a collar. Teachers have a way of regulating their behavior by warning and intimidating. For example, if you don't wear clothes then you will be like this and that? Meanwhile, the formation of social stimulation is carried out by the teacher through the direct practice of these social values in the field, learning through children's games. In class, there are pairs of puzzles, the puzzles contain letters, and numbers are arranged while playing. While outside the classroom, the cat catches the mouse. Children wear police uniforms, there are cops and criminals. The police will be arrested by the police, so you can't be criminals, the implementation in the field by making a circle. Okay, sir, so all the students took part in a game like play role a policy for arresting the wicked person. One child plays as policies and the other children become wicked people. Other students join hands to form a circle where the circle is formed into an arena for police and criminals where in this area the police and criminals will chase each other. If the child in the circle stands up, it is a sign that the door is opened, so criminals or the police may pass under. Meanwhile, if the students who form the circle squat, all the signs are the door is locked. This game contains social values, in this case, namely where children of kindergarten students have social relationships or social relations because they become closer.

When they make a circle, the children's hands with other children will touch each other, and where the handgrips between students do not come off. Meanwhile, others have to squat. Kindergarten children prefer to run around. While slide and swing games and role-playing games, there are social values. The seesaw game must be played in twos. When done by one person then the game does not move. Here there is a lesson for kindergarten children where if the work requires other people and must be done by others. Meanwhile, the value of the swing has the value of cooperation because the swing must be assisted by other people from behind. Another game that is played is 'hide and seek'. Hide and seek is played as a lesson for students. There is a social value of this game which is to practice patience. Finally, the children were also introduced to the history of the vehicle. In the vehicle theme lesson where kindergarten children are taught and the introduction of vehicles in ancient times such as wagons, tricycles, and wagons. This learning method intends to introduce the types of vehicles in the past compared to the present. As a result, the student understands the sorts of vehicles in the previous era. 


\section{CONCLUSION}

Based on results above, it shows that teachers and parents face hurdles when the pandemic strikes the school. Teachers have to transform the manual method like face-to-face learning to the online system. The impact is the parents receive a burden because they face obstacles to adjusting the student behavior at home. Even some parents don't literate in online technology like operating online and some technology programs. It makes the teachers must arrange the method like video calling and try to create some group of learning where the number of students only allow to involve around 1-6 of students. The learning also focuses on reading and calculating or math. Meanwhile, before the covid-19 pandemic come to school life, the teacher still releases material of learning such as my vehicle, universe, and sains. Even teachers still conduct some of the learning including bringing the student in nature for improving the knowledge of student about the part of nature. Furthermore, the teachers bring the student to the zoo to observe the behavior of animals like deer. The goal of this way is to increase the students' knowledge about animals so they recognize the animal in reality in nature. Once the activity is performed, the teacher tries to review again in the class by asking students about what they have viewed and the teacher uses miniatures of animals to recall again the students' memory. Another learning is the teacher use role-playing to add social value in student such as social linkage, social connection, and working together. The social aspect is released on some activities like student performing become policy, playing outside game, and using a traditional game like petak umpet (hide and seek).

\section{REFERENCES}

Abidin, Z., \& Tobibatussa'adah, T. (2021). the Impact of Covid-19 Pandemicon Education and Judicial Practicein Indonesia. Ri'ayah: Jurnal Sosial Dan Keagamaan, 5(02), 123. https://doi.org/10.32332/riayah.v5i02.2794

Amir, L. R., Tanti, I., Maharani, D. A., Wimardhani, Y. S., Julia, V., Sulijaya, B., \& Puspitawati, R. (2020). Student perspective of classroom and distance learning during COVID-19 pandemic in the undergraduate dental study program Universitas Indonesia. BMC Medical Education, 20(1), 1-8. https://doi.org/10.1186/s12909-020-02312-0

Anggito, A., \& Setiawan, J. (2018). Metodologi Penelitian Kualitatif (E. D. Lestari (ed.)). CV Jejak.

Azlan, A. A., Hamzah, M. R., Sern, T. J., Ayub, S. H., \& Mohamad, E. (2020). Public knowledge, attitudes and practices towards COVID-19: A cross-sectional study in Malaysia. PLoS ONE, 15(5), 1-15. https://doi.org/10.1371/journal.pone.0233668

Bangura, M. S., Gonzalez, M. J., Ali, N. M., Ren, R., \& Qiao, Y. (2020). A collaborative effort of China in combating COVID-19. Global Health Research and Policy, 5(1), 20-22. https://doi.org/10.1186/s41256020-00174-Z

Chandra, Y. (2021). Online education during COVID-19: perception of academic stress and emotional intelligence coping strategies among college students. Asian Education and Development Studies, 10(2), 229-238. https://doi.org/10.1108/AEDS-05-2020-0097

Coman, C., Țîru, L. G., Meseșan-Schmitz, L., Stanciu, C., \& Bularca, M. C. (2020). Online teaching and learning in higher education during the coronavirus pandemic: Students' perspective. Sustainability (Switzerland), 12(24), 1-22. https://doi.org/10.3390/su122410367

Espino-Díaz, L., Fernandez-Caminero, G., Hernandez-Lloret, C. M., Gonzalez-Gonzalez, H., \& AlvarezCastillo, J. L. (2020). Analyzing the impact of COVID-19 on education professionals. Toward a paradigm shift: ICT and neuroeducation as a binomial of action. Sustainability (Switzerland), 12(14), 1-10. https://doi.org/10.3390/su12145646

Gore, J., Fray, L., Miller, A., Harris, J., \& Taggart, W. (2021). The impact of COVID-19 on student learning in New South Wales primary schools: an empirical study. In Australian Educational Researcher (Vol. 48, Issue 4). https://doi.org/10.1007/s13384-021-00436-w 
5287 Social, Science and Environment Learning Before Covid-19 and the Learning amid Covid-19 in Nursery Students - Bahagia, Rimun Wibowo, Fachruddin Majeri Mangunjaya, Budi Susetyo DOI: https://doi.org/10.31004/basicedu.v5i6.1511

Hager, E., Odetokun, I. A., Bolarinwa, O., Zainab, A., Okechukwu, O., \& Al-Mustapha, A. I. (2020). Knowledge, attitude, and perceptions towards the 2019 Coronavirus Pandemic: A bi-national survey in Africa. PLoS ONE, 15(7 July), 1-13. https://doi.org/10.1371/journal.pone.0236918

Magdalena, I., Inayah, S., Hidayati, N. D., Jaya, K., \& Tangerang, U. M. (2021). Di Pendidikan Sekolah Dasar Negri Karawaci Baru 1 di Masa Pandemi Covid-19. 3, 346-358.

Munastiwi, E. (2021). Adaptation of Teaching-Learning Models Due to Covid-19 Pandemic: Challenge Towards Teachers Problem-Solving Skills. Jurnal Ilmiah Sekolah Dasar, 5(1), 33-44.

Pokhrel, S., \& Chhetri, R. (2021). A Literature Review on Impact of COVID-19 Pandemic on Teaching and Learning. Higher Education for the Future, 8(1), 133-141. https://doi.org/10.1177/2347631120983481

Puspitasari, D., Nofianto, N., \& Huda, M. I. (2021). Teacher's strategies in survival speaking learning during COVID-19 pandemic. Leksika: Jurnal Bahasa, Sastra Dan Pengajarannya, 15(1), 37. https://doi.org/10.30595/lks.v15i1.9469

Putra, P., Liriwati, F. Y., Tahrim, T., Syafrudin, S., \& Aslan, A. (2020). The Students Learning from Home Experiences during Covid-19 School Closures Policy In Indonesia. Jurnal Iqra': Kajian Ilmu Pendidikan, 5(2), 30-42. https://doi.org/10.25217/ji.v5i2.1019

Rahayu, R. P., \& Wirza, Y. (2020). Teachers' Perception of Online Learning during Pandemic Covid-19. Jurnal Penelitian Pendidikan, 20(3), 392-406. https://doi.org/10.17509/jpp.v20i3.29226

Rukajat, A. (2018). Pendekatan Penelitian Kualitatif (Qualitative Research Approach). CV Budi Utama.

Sintema, E. J. (2020). Effect of COVID-19 on the performance of grade 12 students: Implications for STEM education. Eurasia Journal of Mathematics, Science and Technology Education, 16(7), 1-6. https://doi.org/10.29333/EJMSTE/7893

Sutrisna, I. P. G. (2020). Gerakan Literasi Digital Pada Masa Pandemi Covid-19. Stilistika: Jurnal Pendidikan Bahasa Dan Seni, 8(2), 268-283. https://doi.org/10.5281/zenodo.3884420

Teräs, M., Suoranta, J., Teräs, H., \& Curcher, M. (2020). Post-Covid-19 Education and Education Technology 'Solutionism': a Seller's Market. Postdigital Science and Education, 2(3), 863-878. https://doi.org/10.1007/s42438-020-00164-x

Tria, J. Z. (2020). The COVID-19 Pandemic through the Lens of Education in the Philippines: The New Normal. International Journal of Pedagogical Development and Lifelong Learning, 1(1), ep2001. https://doi.org/10.30935/ijpdll/8311

Vargo, D., Zhu, L., Benwell, B., \& Yan, Z. (2021). Digital technology use during COVID-19 pandemic: A rapid review. Human Behavior and Emerging Technologies, 3(1), 13-24. https://doi.org/10.1002/hbe2.242 